\title{
APLIKASI PETA TITIK RAWAN BANJIR DI KOTA PALEMBANG
}

\author{
Nurul Adha Oktarini Saputri ${ }^{1}$, R.M. Nasrul Halim² \\ ${ }^{1,2}$ Fakultas Ilmu Komputer Universitas Bina Darma Palembang \\ Email: ${ }^{1}$ nuruladhaos@ binadarma.ac.id, ${ }^{2}$ nasrul.zone@gmail.com
}

(Naskah masuk: 12 Desember 2018, diterima untuk diterbitkan: 02 Juli 2019)

\begin{abstract}
Abstrak
Banjir merupakan masalah yang terjadi hampir diseluruh kota di Indonesia, tak terkecuali di kota Palembang. Masalah banjir di kota Palembang sudah menjadi masalah yang serius bagi pemerintah kota Palembang. Banjir di kota Palembang terjadi akibat banjir pasang musiman maupun banjir genangan akibat hujan yang sering terjadi di jalanan. Banjir yang terjadi di jalanan, dapat menyebabkan kerusakan terutama kendaraan baik roda dua maupun roda empat. Selain itu banjir juga dapat menyebabkan kemacetan lalu lintas karena kendaraan harus memperlambat kendaraannya agar tidak merusak kendaraan serta tidak menggangu pengendara lain yang melintas. Permasalahan utama dalam penelitian ini adalah tidak adanya aplikasi untuk mengetahui daerah atau jalan mana saja yang berpotensi terjadinya banjir khususnya di kota Palembang. Oleh sebab itu dibutuhkanlah suatu aplikasi dengan memanfaatkan teknologi komunikasi mobile yang dapat memberikan informasi kepada masyarakat, terutama pengguna kendaraan yang sedang berada di jalan agar dapat terhidar dari bencana banjir. Dengan memanfaatkan layanan titik lokasi menggunakan Google Maps dan API, penulis akan membangun sebuah aplikasi berbasis android, yang bertujuan agar dapat memberikan informasi pengguna kendaraan tentang lokasi titik rawan banjir saat terjadi hujan maupun banjir musiman di jalan-jalan kota Palembang, sehingga dapat membantu pengendara menghidari kerusakan kendaraan akibat banjir serta dapat membantu mengurangi kemacetan pada saat terjadinya banjir agar dapat menghemat waktu perjalanan.
\end{abstract}

Kata kunci: android, API, banjir, google maps

\section{APPLICATION OF FLOOD-PRONE POINT MAP IN PALEMBANG CITY}

\begin{abstract}
Flooding is a problem that happens almost throughout the city in Indonesia, no exception in Palembang city. The problem of flooding in the Palembang city has become a serious problem for the Government. Flooding in Palembang occur due to tidal flooding or flood inundation due to seasonal rains that often occur in the streets. The flooding that occurred on the streets, can cause damage especially two-wheel vehicles or four wheel. In addition to flooding can also cause traffic congestion because the vehicles had to slow down their vehicles so as not to damage the vehicle and does not interfere with other riders crossing. The main problem in this research is the lack of application to know which road areas or potential occurrence of flooding especially in Palembang. Therefore it needs an application by making use of mobile communication technology that can provide information to the public, especially users vehicles that are on the way so it can be terhidar from the flood. By utilizing the service point location using Google Maps and API, the author will build an android-based applications, the aim is to be able to provide information about the location of the point of vehicle users prone to flooding in the event of rain or flood seasonal in the streets of the city of Palembang, so you can help motorists avoid vehicle damage due to flooding and can help reduce congestion at the time of the occurrence offlooding in order to save on travel time.
\end{abstract}

Keywords: android, API, flood, google maps

\section{PENDAHULUAN}

Banjir merupakan masalah yang terjadi hampir diseluruh kota di Indonesia, tak terkecuali di kota Palembang. Masalah banjir di kota Palembang sudah menjadi masalah yang serius bagi pemerintah kota Palembang terutama bagi Dinas Pekerjaan Umum
(PU) dan Dinas Penataan Ruang kota Palembang. Banjir di kota Palembang terjadi akibat banjir pasang musiman maupun banjir genangan akibat hujan yang sering terjadi di jalanan di kota Palembang. Banjir akibat hujan di Kota Palembang di beberapa lokasi dapat mencapai $30 \mathrm{~cm}$ atau sebetis orang dewasa, sehingga bagi pengendara dapat 
menggangu perjalanan. Banjir yang terjadi di jalanan, dapat menyebabkan kerusakan terutama kendaraan baik roda dua maupun roda empat. Selain itu banjir juga dapat menyebabkan kemacetan lalu lintas karena kendaraan harus memperlambat kendaraannya agar tidak merusak kendaraan serta tidak menggangu pengendara lain yang melintas. Agar tidak terjadi hal tersebut, biasanya pengendara menghindari jalanan yang tergenang banjir dengan cara mencari jalur atau jalan alternatif yang tidak tergenang banjir untuk dilalui.

Permasalahan utama dalam penelitian ini adalah tidak adanya aplikasi untuk mengetahui daerah atau jalan mana saja yang berpotensi terjadinya banjir khususnya di kota Palembang. Oleh sebab itu dibutuhkanlah suatu aplikasi dengan memanfaatkan teknologi komunikasi mobile yang dapat memberikan informasi kepada masyarakat, terutama pengguna kendaraan yang sedang berada di jalan agar dapat terhidar dari bencana banjir.

Penggunaan teknologi komunikasi berbasis mobile salah satunya adalah smartphone saat ini bukan hanya sekedar sebagai alat komunikasi, tetapi sudah banyak aplikasi atau layanan yang beragam dan bermanfaat bagi pengguna. Selain itu smartphone ini juga sudah dilengkapi dengan sistem navigasi yang dikenal dengan nama Global Positioning System (GPS), sehingga dapat memberikan informasi lokasi seseorang berada. GPS adalah sebuah sistem telekomunikasi terbuka, tidak ada pemilikan (non-proprietary) melainkan kepemilikan hak cipta suatu perusahaan yang berkembang secara pesat dan konstan (Sunomo dalam Ziad, 2013). GPS (Global Positioning System) adalah sebuah sistem atau proses untuk menentukan suatu posisi, manapun di planet bumi ini berdasarkan 4 faktor: latitude, longitude, altitude dan time (Firdaus, 2013). Salah satu aplikasi di smartphone yang menggunakan sistem navigasi GPS adalah Google Maps.

Google Maps adalah layanan gratis yang diberikan oleh Google dan sangat popular. Google Maps adalah suatu peta dunia yang dapat kita gunakan untuk melihat suatu daerah. Dengan kata lain, Google Maps merupakan suatu peta yang dapat dilihat dengan menggunakan suatu browser. Kita dapat menambahkan fitur Google Maps dalam web yang telah kita buat atau pada blog kita yang berbayar maupun gratis sekalipun dengan Google Maps API. Google Maps API adalah suatu library yang berbentuk JavaScript (Ariyanti, 2015).

Google Maps merupakan aplikasi peta digital dunia yang diluncurkan oleh perusahaan raksasa dunia Google inc. Google Maps dapat dimanfaatkan untuk pencarian lokasi apapun di dunia. Selain itu agar dapat dikembangkan, Google menyediakan Application Program Interface (API) yang sangat berguna bagi pengembang aplikasi dengan memanfaatkan beberapa fitur yang disediakan Google, misalnya dalam mengembangkan aplikasi pencarian titik lokasi dengan GPS yang berbasis Location Based Service (LBS). LBS adalah layanan informasi yang dapat diakses melalui mobile device dengan mengunakan mobile network, yang dilengkapi kemampuan untuk memanfaatkan lokasi dari mobile device tersebut. LBS memberikan kemungkinan komunikasi dan interaksi dua arah. Oleh karena itu pengguna memberitahu penyedia layanan untuk mendapatkan informasi yang dia butuhkan, dengan referensi posisi pengguna tersebut. (Imaniar dalam Widyaningsih, 2016).

Dengan memanfaatkan layanan titik lokasi menggunakan Google Maps dan API penulis akan mengembangkan sebuah aplikasi berbasis android yang bertujuan agar dapat memberikan informasi pengguna kendaraan tentang lokasi titik rawan banjir saat terjadi hujan maupun banjir musiman di jalanjalan kota Palembang, sehingga dapat membantu pengendara menghidari kerusakan kendaraan akibat banjir serta dapat membantu mengurangi kemacetan pada saat terjadinya banjir agar dapat menghemat waktu perjalanan.

\section{METODE PENELITIAN}

\subsection{Jenis Data}

Jenis data yang digunakan adalah data primer dan data sekunder. Data primer dalam penelitian ini berupa data titik lokasi rawan banjir, data jalan di kota palembang, sedangkan data sekunder berupa literatur dan jurnal serta penelitian lain yang berhubungan dengan penelitian ini.

\subsection{Metode Pengumpulan Data}

Pengumpulan data menggunakan metode observasi, wawancara dan studi pustaka. Observasi dilakukan dengan menunjungi titik lokasi yang dianggap rawan terjadi banjir melalui data-data yang didapatkan dari dinas pekerjaan umum kota Palembang. Wawancara dilakukan dengan tanya jawab dengan kepala staf kantor dinas pekerjaan umum kota Palembang dan kepada pengguna jalan khususnya pengendara roda 2 dan roda 4 mengenai masalah yang akan diteliti. Sedangkan studi pustaka dilakukan mencari dan mengumpulkan jurnal-jurnal, buku maupun informasi lainnya sebagai bahan referensi untuk menunjang penelitian ini.

\subsection{Metode Pengembangan Perangkat Lunak}

Metode pengembangan perangkat lunak ini menggunakan metode mobile-D. Tahapan metode pengembangan mobil-D (Ependi, 2017):

1) Explore, merencanakan dan menyusun proyek yang akan dikerjakan. Tahap ini meletakkan isuisu dasar pengembangan sistem, antara lain arsitektur produk, proses pengembangan dan lingkungan pengembangan.

2) Initialize, menyiapakan dan memverifikasi semua isu-isu kritis dalam pengembangan yang 
menentukan keberhasilan proyek. Diakhir tahap ini diharapkan semua sumber daya telah siap untuk memulai membangun sistem yang dibuktikan dengan adanya hasil perancangan.

3) Productionize, mengimplementasikan semua kebutuhan fungsional pada produk dengan menerapkan siklus pengembangan secara iterative dan bertingkat.

4) Stabilize, mengintegrasikan sub sistem yang telah dibangun menjadi satu kesatuan produk dengan menerapkan siklus pengembangan secara iterative dan bertingkat.

5) System test and fix, menguji dan melakukan perbaikan sistem. Hasil dari pengujian akan menjadi umpan balik bagi tim pengembang untuk memperbaiki kekurangan sistem.

Untuk lebih jelasnya tahapan metode pengembangan aplikasi mobile- $D$, dapat dilihat pada Gambar 1.

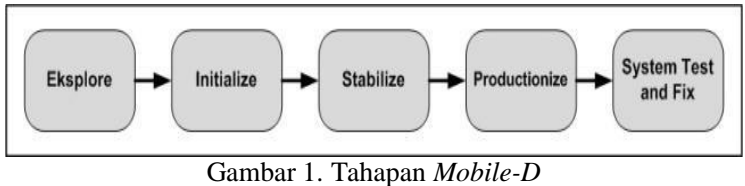

\section{HASIL DAN PEMBAHASAN}

Hasil dari penelitian ini berupa aplikasi peta titik rawan banjir di kota Palembang berbasis android yang baru sebatas aplikasi dengan format apk, dan belum tersedia di playstore. Untuk mengakses aplikasi ini dengan cara menggandakan aplikasi yang dapat dikirimkan dari smartphone sumber dan tujuan.

\subsection{Explore}

Tahap ini merupakan proses mengidentifikasi ruang ringkup aplikasi mobile yang akan dibuat antara lain menentukan kebutuhan perangkat keras dan perangkat lunak dan perancangan diagram UML seperti use case, activity diagram dan class diagram.

Kebutuhan perangkat lunak yang dibutuhkan untuk membangun aplikasi ini dapat dilihat pada Tabel 1.

\begin{tabular}{lll}
\multicolumn{3}{c}{ Tabel 1. Spesifikasi Perangkat Lunak } \\
\hline Komponen & & Spesifikasi Software \\
\hline Laptop & OS & Windows 7 \\
& Program & Xampp, Apache 2.2, MySQL, \\
& & Eclipse Luna, Android \\
& & Development Tool V.23, \\
& & Notepad++ (coding PHP) \\
Smartphone & OS & Android 4.0 atau lebih \\
\hline
\end{tabular}

Kebutuhan perangkat keras yang diperlukan untuk mengembangkan Aplikasi Peta Titik Rawan Banjir berbasis Android di Kota Palembang dapat dilihat pada Tabel 2 .

Tabel 2. Spesifikasi Perangkat Keras

\begin{tabular}{lll}
\multicolumn{3}{c}{ Tabel 2. Spesifikasi Perangkat Keras } \\
\hline \multicolumn{1}{c}{ Komponen } & \multicolumn{2}{c}{ Spesifikasi Hardware } \\
\hline Laptop & Processor & Intel Core i3 \\
& RAM & 2GB \\
\hline
\end{tabular}

\begin{tabular}{clc}
\hline Komponen & & Spesifikasi Hardware \\
\hline & HDD & 320GB \\
\hline Smartphone & Processor & Quadcore 1.8ghz \\
& RAM & 2GB atau lebih \\
& ROM & 8GB atau lebih \\
\hline
\end{tabular}

Detail fungsi pada aplikasi yang akan dibuat adalah sebagai berikut:

1) Adanya pengelolaan data informasi titik rawan banjir di sisi back-end agar informasi titik rawan dapat selalu diperbaharui.

2) Aplikasi dapat menampilkan informasi titik rawan banjir dengan bantuan penanda.

3) Menampilkan informasi cuaca yang mendukung keadaan banjir di suatu jalan di Kota Palembang.

4) Memberikan peringatan baik berupa tulisan atau gambaran atau juga suara, jika pengendara cukup dekat dengan daerah banjir.

5) Aplikasi mampu mengatur apakah peringatan diaktifkan atau tidak, dan berapa jarak minimum peringatan akan ditampilkan.

Rancangan use case diagram seperti Gambar 2, dimana terdapat dua aktor yaitu admin dan pengguna. Aktivitas yang dapat dilakukan seorang admin pertama kali adalah login terlebih dulu untuk dapat masuk ke dalam sistem untuk dapat menentukan dan menambah data titik rawan banjir. Sedangkan yang dapat dilakukan pengguna yaitu melihat informasi cuaca, melihat informasi titik rawan banjir dan melakukan pengaturan.

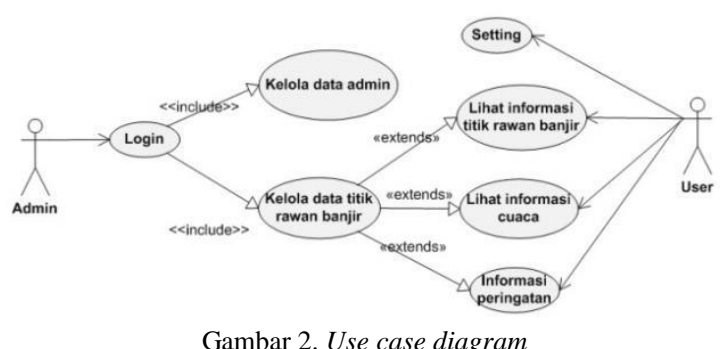

Activity diagram merupakan gambaran aktivitas yang dapat dilakukan oleh aktor terhadap aplikasi yang dibuat. Activity diagram pengguna dapat dilihat pada Gambar 3.

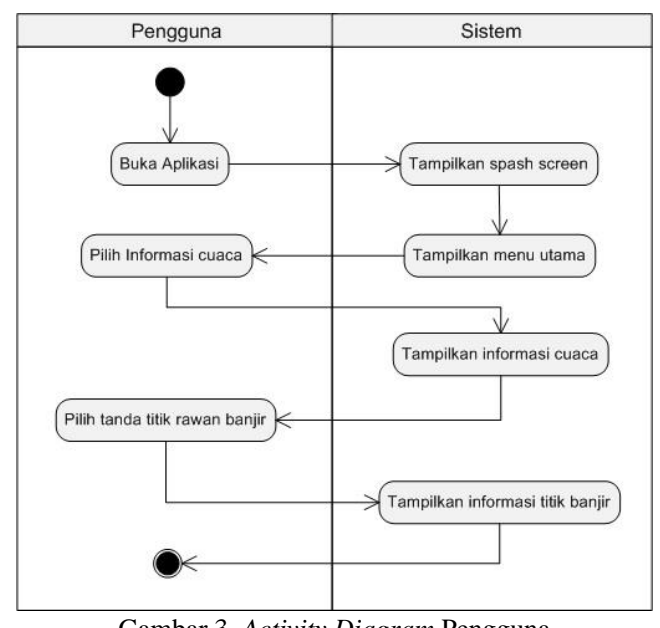

Gambar 3. Activity Diagram Pengguna 
Pada Gambar 3, dapat dilihat aktivitas apa saja yang dapat dilakukan oleh seorang user terhadap aplikasi yang akan dibuat, dimulai dari membuka aplikasi, memilih aktivitas yang dapat dilakukan, seperti melihat titik-titik daerah rawan banjir dalam bentuk penanda. Activity diagram untuk admin dapat dilihat pada Gambar 4.

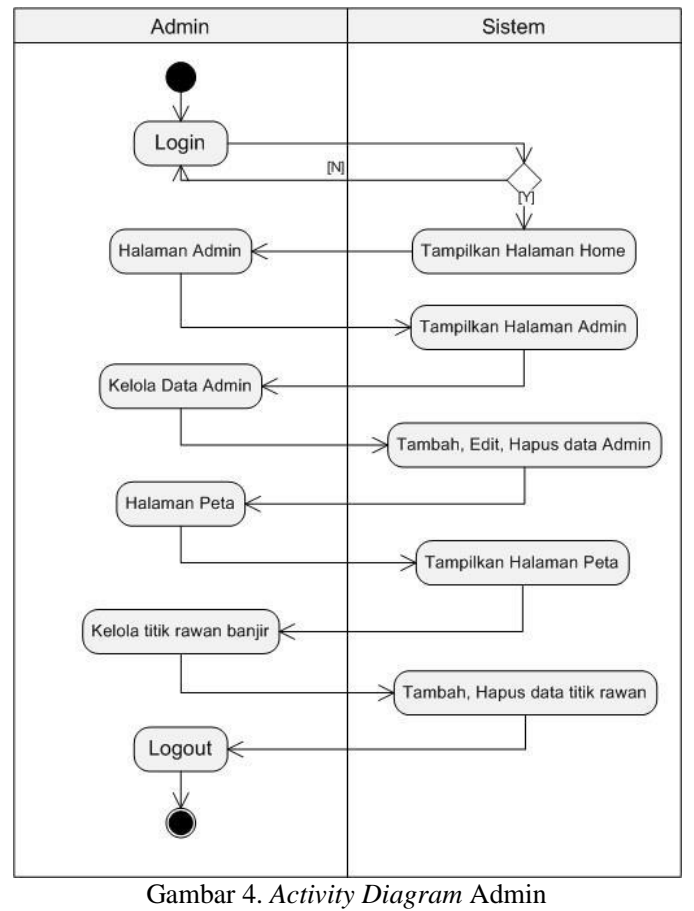

Rancangan selanjutnya adalah rancangan class diagram seperti pada Gambar 5. Terdapat 6 class yang saling terhubung dan masing-masing memiliki perintah yang dapat dilakukan.

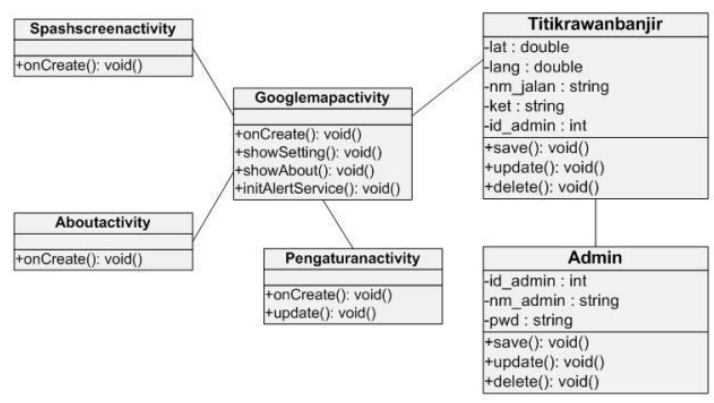

Gambar 5. Class Diagram

\subsection{Initialize}

Tahapan initialize merupakan tahapan menterjemahkan rancangan arsitektur aplikasi ke dalam bentuk rancangan antarmuka aplikasi peta daerah rawan banjir di kota Palembang secara visual.

Gambar 6 merupakan salah satu rancangan antarmuka aplikasi peta daerah rawan banjir di kota Palembang berbasis android untuk menentukan titiktitik lokasi rawan banjir di kota Palembang yang terhubung dengan Google Maps. Rancangan ini merupakan aktivitas yang hanya dapat dilakukan oleh seorang admin.

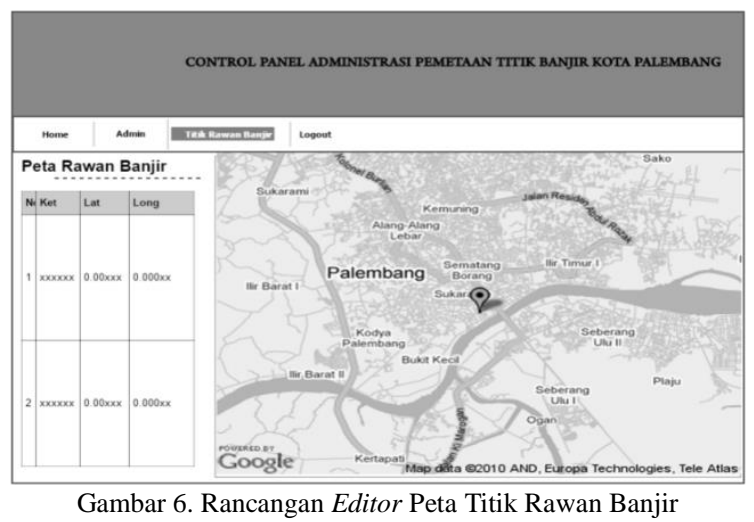

\subsection{Productionize}

Tahap Productionize merupakan tahapan penerapan dari semua rancangan yang sudah dibuat dalam bentuk aplikasi yang sebenarnya menggunakan berbagai aplikasi. Pembangunan aplikasi untuk administrator menggunakan bahasa pemrograman PHP dengan editor Notepad++ dan database MySQL karena akses antarmuka adminsitrator menngunakan browser, sedangkan untuk pembangunan antarmuka pengguna eclipse Luna, Android Development Tool dan lain-lain

Antarmuka halaman utama selain menampilkan marker informasi titik rawan banjir, kita dapat melihat kondisi cuaca dan peringatan, seperti pada Gambar 7.

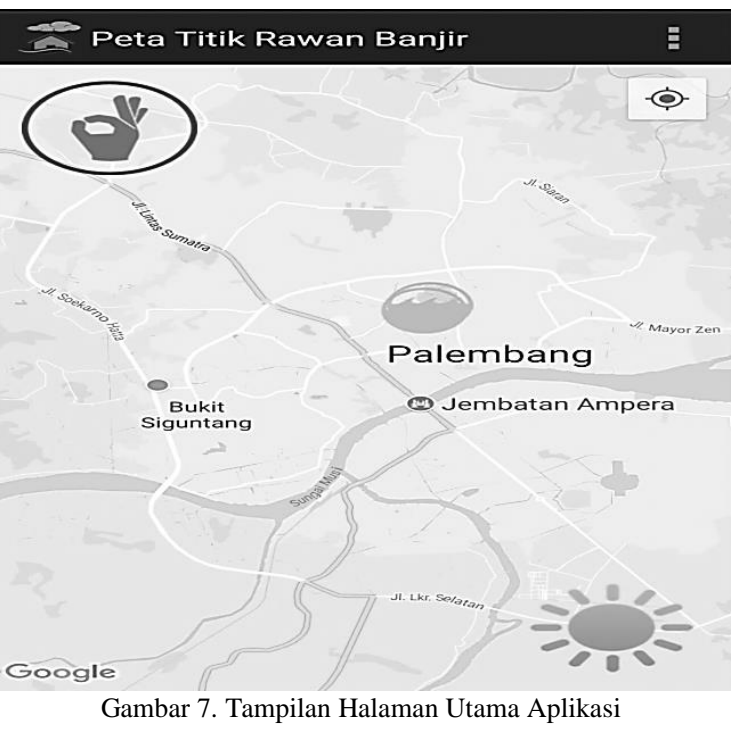

Proses banjir dapat diketahui di peta dalam aplikasi ini pada saat terjadi hujan maka akan muncul peringatan cuaca dalam keadaan hujan, kemudian akan muncul titik-titik daerah rawan banjir yang akan muncul di peta. Peringatan cuaca seperti pada Gambar 7, kita dapati cuaca dalam keadaan panas terik, sedangkan peringatan dalam keadaan "OK" atau aman. Pada kesempatan lain, 
cuaca dapat berubah dalam keadaan sedang hujan atau tanda peringatan menunjukkan tanda seru yang berarti menunjukkan keadaan benar-benar dalam masalah serius dan kemungkinan titik-titik rawan banjir akan muncul. Jika cuaca hujan sudah reda maka status banjir akan kembali dalam keadaan aman.

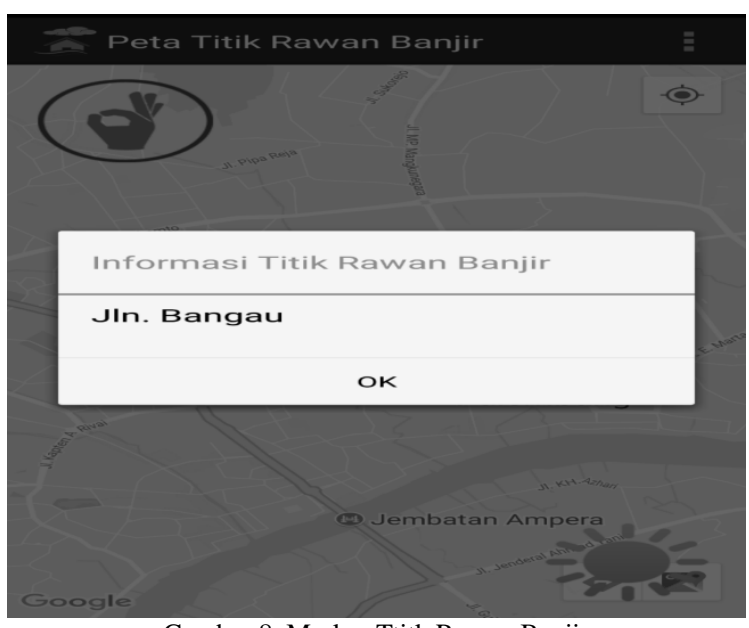

Gambar 8. Marker Ttitk Rawan Banjir

Seluruh informasi titik rawan banjir ditampilkan dalam bentuk marker atau tanda berupa icon banjir pada lokasi rawan banjir. Pengguna dapat mengetahui informasi jalan yang merupakan daerah rawan banjir tersebut dengan cara meng-klik-nya seperti pada Gambar 8 .

Pemberitahuan lokasi titik rawan banjir dapat diatur sesuai dengan keinginan pengguna. Peringatan akan diberitahukan selama pengguna berada pada jarak tertentu yang sesuai dengan pengaturan seperti pada Gambar 9.

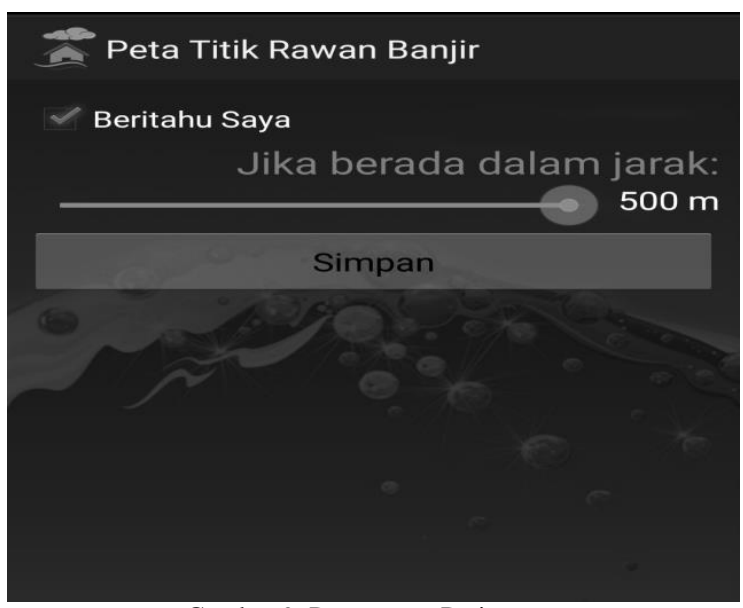

Gambar 9. Pengaturan Peringatan

\subsection{Stabilize}

Setelah tahapan pembangunan selesai, selanjutnya adalah tahapan Stabilize, yaitu menyatukan sub-sub sistem menjadi satu aplikasi yang dapat dipasang pada perangkat mobile .

\subsection{System Test and Fix}

Tahapan terakhir adalah proses pengujian terhadap aplikasi yang dibuat. Pengujian dilakukan terhadap aplikasi peta titik rawan banjir di kota Palembang yang berbasis android menggunakan pendekatan blackbox. Pengujian blackbox merupakan pengujian terhadap fungsional aplikasi. Untuk melakukan pengujian dibuatlah skenario pengujian yang dapat dilihat pada tabel 3 .

Tabel 3. Hasil Pengujian Aplikasi

\begin{tabular}{lll}
\hline \multicolumn{1}{c}{ Komponen } & \multicolumn{1}{c}{ Pengujian } & \multicolumn{1}{c}{ Hasil } \\
\hline Form Admin & Tambah & Diterima \\
& Edit & Diterima \\
& Hapus & Diterima \\
Form Titik & Tambah & Diterima \\
rawan banjir & Edit & Diterima \\
& Hapus & Diterima \\
Form & Checkbox dipilih & Diterima \\
Pengaturan & Checkbox tidak dipilih & Diterima \\
pemberitahuan & & \\
\hline
\end{tabular}

\section{KESIMPULAN}

Berdasarkan hasil penelitian yang telah dilakukan, maka dapat disimpulkan penelitian ini menghasilkan aplikasi peta daerah rawan banjir di kota Palembang berbasis Android. Aplikasi yang dihasilkan hanya sebatas apk belum bisa diunduh dari playstore. Aplikasi ini dapat dijadikan sebagai alat bantu bagi masyarakat terutama pengendara kendaraan baik roda dua maupun roda empat untuk dapat melihat titik lokasi mana saja yang berpotensi terjadi banjir sehingga pengendara dapat menghindari daerah tersebut sehingga dapat mengurangi dampak kerusakan dan kemacetan akibat banjir.

Untuk pengembangan selanjutnya agar dapat dikembangkan juga di platform IOS (apple) serta dapat menambahkan fitur-fitur yang lebih baik dan tampilan yang lebih menarik lagi.

\section{DAFTAR PUSTAKA}

ARIYANTI，RENA，DKK. 2015. Pemanfaatan Google Maps API pada Sistem Informasi Geografis Direktori Perguruan Tinggi Di Kota Bengkulu. Jurnal Media Infotama, Universitas Dehasen Bengkulu, Vol.11(2), p.119-129. [e-journal]. Tersedia melalui: <https://jurnal.unived.ac.id/index.php/jmi/a rticle/view/259/238> [Diakses 2 Juli 2018]

EPENDI, USMAN. 2017. Mobile Application Monitoring Pengisian Uang Anjungan Tunai Mandiri PT Bank Mandiri Cabang Palembang. Jurnal Edukasi dan Penelitian Informatika, Universitas Tanjungpura, vol.3(1), p.33-39. [e-journal]. Tersedia melalui:

<http://jurnal.untan.ac.id/index.php/jepin/ar ticle/view/20115/16564> [Diakses 2 juli 2018] 
456 Jurnal Teknologi Informasi dan Ilmu Komputer (JTIIK), Vol. 6, No. 4, Agustus 2019, hlm. 451-456

FIRDAUS, O.M. 2013. Analisis Implementasi Global Positioning System (GPS) pada Moda Transportasi di PT. "X". Seminar on Application and Research in Industrial Technology. Universitas Widyatama, p.B83-B88. Tersedia melalui <https://repository.widyatama.ac.id/xmlui/b itstream/handle/123456789/2072/content.p df?sequence $=1>$ [Diakses 2 Juli 2018]

WIDYANINGSIH, ASTI, DKK. 2016. Penyediaan Aplikasi Layanan Lokasi Berbasis Location Based Service (LBS). Jurnal SCRIPT, IST AKPRIND Yogyakarta, Vol.4(1), p.18-26. [e-journal]. Tersedia melalui: <https://journal.akprind.ac.id/index.php/scri pt/article/viewFile/1059/742w> [Diakses 2 Juli 2018]

ZIAD, IBNU. 2013. Rancang Bangun Pelacak Lokasi dengan Teknologi GPS. Jurnal Teknomatika, STMIK PALCOMTECH Palembang, Vol.3(1), p.1-13. [e-journal]. Tersedia melalui: <http://news.palcomtech.com/wpcontent/uploads/IBNUZIAD_TE03012013. pdf> [Diakses 2 Juli 2018]. 